\title{
溶接缶向け新 $\mathrm{Nb}-\mathrm{B}$ 複合添加極低炭素鋼板の開発
}

\author{
多田雅 毅苗) 小島克己炎) 岩佐 浩 樹*) \\ 梅本雅資炎) 堀田英 輔* $_{4}^{*}$
}

\section{1. は じめに}

缶用鋼板には, 連続焼鈍ライン (CAL: Continuous Annealing Line)を用いた焼鈍か，バッチ焼鈍炉(BAF: Batch Annealing Furnace)による焼鈍が施されている.2004年の 当社西日本製鉄所 (福山地区) 錫鍍金工場の缶用鋼板の CAL 比率は78\%(1) と低いのが現状であった. BAF 材を CAL 化 すると，(i)製造コストが削減でき，(ii)CAL 稼働率が向上し， (iii)リードタイムを平均 10 日短縮することによる在庫削減効 果が期待できる.このため, 錫鍍金工場の CAL 比率向上を 推進している.

缶用鋼板の強度は, JIS G 3303にあるロックウェルスー パーフィシャル硬さ (HR30T)に対応した調質度という指標 で示される. 一回圧延製品の調質度は T-1 から $\mathrm{T}-5$ まで規 定されていて，数字が大きくなるにしたがって強度が高くな っている．錫鍍金工場で製造されている午用鋼板の焼鈍方法 の内訳は，T-4 以上の硬質材では CAL 材がほぼ $100 \%$ あ るのに対して, T-3 以下の軟質材では BAF 材が $50 \%$ 以上と なっている.この中では, $\mathrm{T}-2$ から T-2.5の大型溶接缶 (ペ 一ル午等) と, T-3の食油溶接缶が多数を占めている.

本報告では, 大型溶接缶の必要特性を満たす, CAL で焼 鈍された新 $\mathrm{Nb}-\mathrm{B}$ 複合添加極低炭素鋼板を世界で初めて開 発し, あわせて製造上の課題も解決したので, その概要を紹 介する。

\section{2. 大型溶接缶の必要特性}

大型溶接缶に必要な特性として, (a)鋼板強度, (b)エキスパ ンド加工後の周方向缶高さ変化の抑制, (c)非時効性, (d)高溶 接強度の 4 つが挙げられる.

* JFE スチール株式会社

スチール研究所 缶・ラミネート材料研究部 :

1)主任研究員 2)部長

3)西日本製鉄所錫鍍金部錫鍍金技術室主任部員

4) 東日本製鉄所第 1 冷延部冷延技術室主任部員

Development of New Nb and B-added Extra Low-carbon Steel Sheets for Pail Cans; Masaki Tada, Katsumi Kojima, Hiroki Iwasa, Masashi Umemoto, Eisuke Hotta(JFE Steel Corporation)

2009年10月30日受理

\section{(a) 鋼板強度}

鋼板強度が T-2, T-3 の目標值であること(HR30T で T$2: 53$ 前後, $\mathrm{T}-3: 57$ 前後) が必要である.

(b) エキスパンド加工後の周方向缶高さ変化の抑制

図 1 にエキスパンド加工後の周方向缶高さ変化の抑制の模 式図を示す. 缶高さ変化の抑制はランクフォード值 $(r$ 值 $)$ と 相関があり, 低 $r$ 值材は高 $r$ 值材と比べて, 加工前後での缶 高さ変化が小さい.これは, $r$ 值 $(r=\varepsilon w / \varepsilon t, w$ : 幅方向真ひ ずみ, $\varepsilon t$ : 厚さ方向真ひずみ) が低下すると, 板厚の変化量 が増加し, 板幅方向(缶の高さ方向に相当)の変化量が減少す るためである. 缶高さ変化量が大きい場合, 硬くて伸びが小 さい溶接部が出っ張るために, 天地板の巻締め不良の原因と なる・

特に, 压延方向 ( $\mathrm{L}$ 方向) に対して $90^{\circ}$ の方向 (C方向) の $r$ 值 $(r c$ 值) が重要である. その理由は, 缶胴の周方向は $\mathrm{C}$ 方 向である場合が多いためである.よって, エキスパンド加工 後の周方向缶高さ変化の抑制のためには $r$ 值を現行の BAF 材並に留めることが必要である。

(c) 非時効性

エキスパンド加工後に缶胴部でストレッチャーストレイン が発生しないことが必要である。ストレッチャーストレイン の発生は降伏点伸び (YP-El) と相関があり, $\mathrm{YP}-\mathrm{E} 1$ の発生 を抑制することが必要である.

\section{（d）高溶接強度}

溶接強度は図 2 に示すテアリング試験で評価を行う.

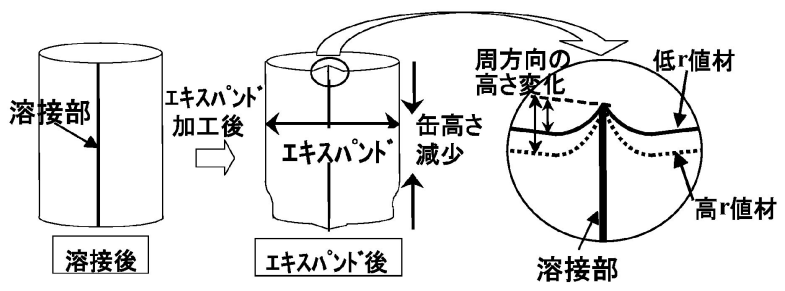

図 1 エキスパンド加工後の周方向缶高さ変化の抑制 模式図. 

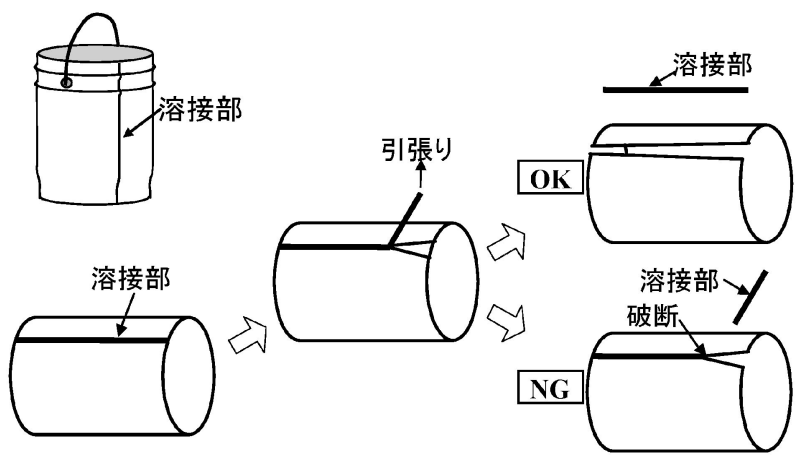

図 2 テアリング試験方法.

テアリング試験とは溶接部を引き裂くことによって溶接部 の強度を評価する試験法である. 評価が簡易に行えるため, 製缶メーカーでは広く用いられている方法である. 溶接強度 が十分であると判断されるためには, 溶接部が途中で切れず に全て引き裂ける必要がある。連続焼鈍された $\mathrm{Nb}$ 添加極低 炭素鋼板 (以降, 現行 CAL 材) では溶接部が途中で切れる場 合があった。

\section{3. 新 $\mathrm{Nb}-\mathrm{B}$ 複合添加極低炭素鋼板の開発}

上記の必要特性を満たすために，極低炭素鋼に $\mathrm{Nb}, \mathrm{B}$ を 複合添加した新規連続焼鈍鋼板 (以降, 開発 CAL 材) を開発 した. 以下にその特徵を述べる.

\section{（1）機械的特性}

表 1 に開発 CAL 材の機械的特性を現行 CAL 材, BAF 材 と比較して示す. 開発 CAL 材は BAF 材並久の鋼板強度(調 質度）と低 $r c$ 值を有している．これには，Bのドラッギング 効果によるフェライト結晶粒の細粒化 ${ }^{(2)-(4)}$ が影響している と考えられる. 図 3 に開発 CAL 材と現行 CAL 材の組織写 真を示す．Bを添加することによって結晶粒の成長が抑制さ れている様子が観察された。焼鈍時の粒成長が抑えられてい ることから, 圧延安定方位 $\{001\}\langle 110\rangle$ がそのまま残存しや すいために $r c$ 值が低下した(5) と考えられる.

さらに，開発 CAL 材は $\mathrm{Nb}$ にって固溶 C が $\mathrm{NbC}$ とし て固定されるため YP-El は観察されず, 非時効性が確保さ れている.

開発 CAL 材は大型溶接缶の必要特性の (a)鋼板強度, (b)工 キスパンド加工後の周方向缶高さ変化の抑制, (c)非時効性を 満たしている.

\section{（2）溶接性}

テアリング試験時の溶接部破断を回避するためには，溶接 部および熱影響部の硬度を上昇させることが必要である. 図 4 に $\mathrm{Nb}$ 添加極低炭素鋼板へB を添加したときの母材に対 する溶接部硬度上昇量 $\Delta \mathrm{Hv}$ を調査した結果を示す． B 含有 量を増やすことで, テアリング試験合格となる溶接部強度に 到達すると考えられる. B 添加で溶接部の硬度が上昇したの は, $\gamma \rightarrow \alpha$ 変態遅延による核発生頻度の増加, および B の偏 析 ${ }^{(4)}$ によって結晶粒が微細化し, 強度が上昇したためと考え られる。

図 5 に実機でシーム溶接を実施したサンプルの溶接部硬度 分布を示す. 開発 CAL 材は現行 CAL 材と比較して, BAF 材並に溶接部硬度が上昇し, テアリング試験も合格となった.

表 1 開発 CAL 材 (調質度 T-2)の機械特性值の例.

\begin{tabular}{lccccccc}
\hline \hline & $\begin{array}{c}\text { 板厚 } \\
(\mathrm{mm})\end{array}$ & $\begin{array}{c}\mathrm{YP} \\
(\mathrm{MPa})\end{array}$ & $\begin{array}{c}\mathrm{YP}-\mathrm{E} 1 \\
(\%)\end{array}$ & $\begin{array}{c}\mathrm{TS} \\
(\mathrm{MPa})\end{array}$ & $\begin{array}{c}\mathrm{E} 1 \\
(\%)\end{array}$ & $r c$ 值 & HR30T \\
\hline 開発 CAL 材 & 0.4 & 260 & 0.0 & 350 & 40 & 1.8 & 51 \\
現行 CAL 材 & 0.4 & 240 & 0.0 & 350 & 41 & 2.0 & 51 \\
BAF 材 & 0.4 & 240 & 0.0 & 350 & 40 & 1.8 & 51 \\
\hline
\end{tabular}

(a) 開発CAL材

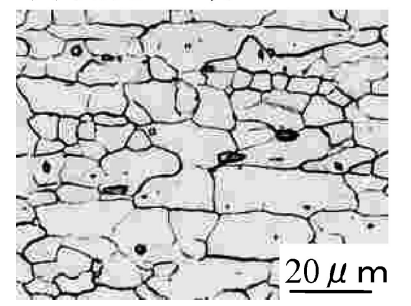

(b) 現行CAL材

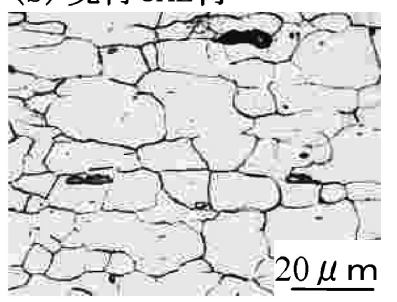

図 3 開発材 CAL 材と現行 CAL 材の組織写真.

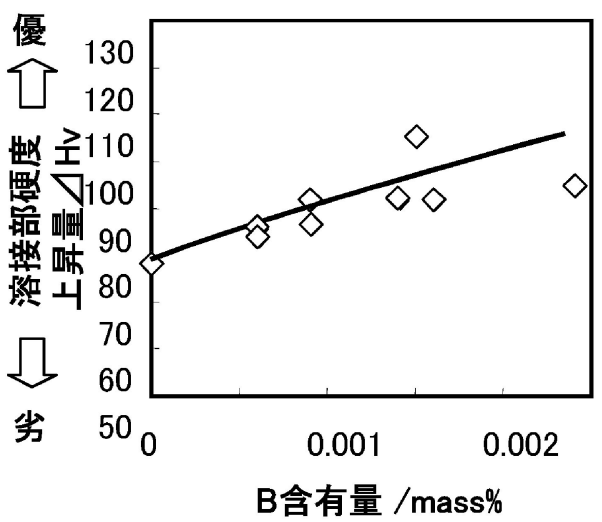

図 4 B 含有量と溶接部硬度上昇量の関係.

\section{4. 製造上の課題解決のための成分最適化}

(1) 再結晶温度上昇の抑制

図 6 に開発 $\mathrm{CAL}$ 材の $\mathrm{B} / \mathrm{N}$ 原子比と再結晶温度の関係を 示す。

$\mathrm{B} / \mathrm{N}$ 原子比が大きくなると再結晶温度が大幅に上昇して 未再結晶組織が残存する. 再結晶温度が上昇するのは BN と して析出しない固溶 B が粒界偏析することによって, 粒界 移動を抑制するためと考えられる. B / N 原子比を低下させ ることで CALの操業条件を変更せずに焼鈍することが可能 となった。

\section{（2）熱間延性低下の抑制}

図 7 に開発 CAL 材で連続鋳造時に発生したスラブ上面の コーナー割れ写真を示す。現行 CAL 材では起こらない熱間 延性の低下が観察された.

図 8 に高温引張試験後の該当材の破面を SEM 観察した結 果を示す. 高温引張試験は高周波誘導方式の熱間加工再現試 験機で, 平行部直径 $8 \mathrm{~mm}$, 平行部長さ $15 \mathrm{~mm}$ の丸棒を用 いて真空中で実施した。熱履歴は $1420^{\circ} \mathrm{Cで} 60$ 秒均熱後, $-5^{\circ} \mathrm{C} / \mathrm{s}$ で急冷して, 試験温度 $950^{\circ} \mathrm{C}$ で 60 秒保持し引張試験 を行った．ひずみ速度は, 連続鋳造の曲げ曲げ戻しの変形に 対応した低ひずみ速度 $\left(2 \times 10^{-3} / \mathrm{s}\right)$ で実施した。熱間延性の 評価には，破断後の破断面の絞り值(断面減少率)を用いた.

破断面より $\mathrm{MnS}$ を核とした BN の複合析出物が $\gamma$ 粒界 


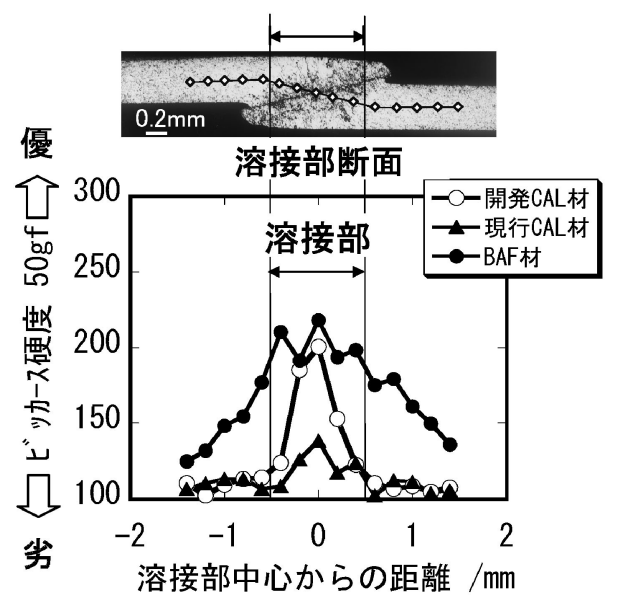

図 5 シーム溶接部硬度分布.

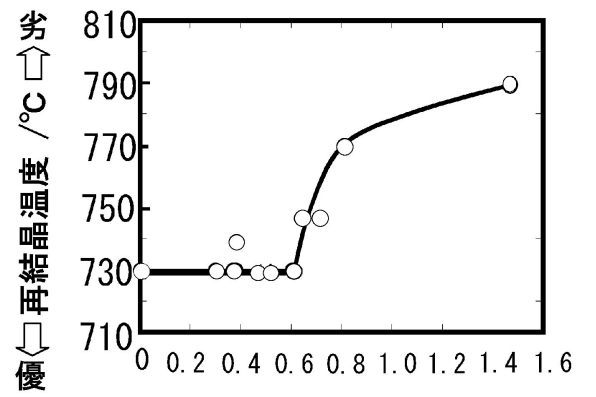

$\mathrm{N}$ 量高 $\boxminus \mathrm{B} / \mathrm{N}$ 原子比 $\Rightarrow \mathrm{N}$ 量低

図 6 開発 $\mathrm{CAL}$ 材の $\mathrm{B} / \mathrm{N}$ 原子比と再結晶温度の関係.
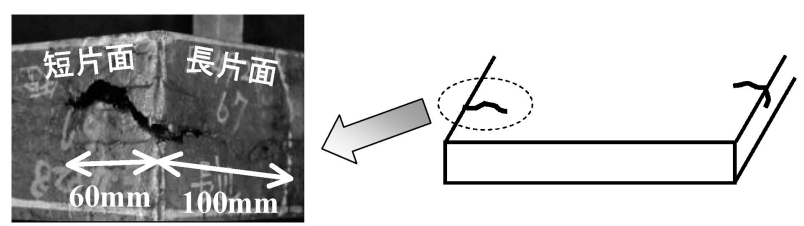

図 7 スラブ上面に発生したスラブ割れ写真.

に，また，粒内に $\mathrm{Nb}(\mathrm{C}, \mathrm{N})$ の析出物が観察された。これよ り, $\mathrm{MnS}+\mathrm{BN}$ が $\gamma$ 粒界に析出し粒界延性破壊を, $\mathrm{Nb}(\mathrm{C}, \mathrm{N})$ が $\gamma$ 粒内に析出し粒を硬化させ粒内脆性破壊する 相乗効果で熱間延性が低下したと考えられる.

よって，核となる $\mathrm{MnS}$ または $\mathrm{BN}, \mathrm{Nb}(\mathrm{C}, \mathrm{N})$ の析出量を 抑えることで熱間延性の低下を抑制することができると考え られる，この中で， $\mathrm{S}$ 量低減は脱硫コス卜上昇， B 量低減は 溶接性低下, $\mathrm{Nb}$ 量低減は固溶 $\mathrm{C}$ 量が増加し $\mathrm{YP}-\mathrm{El}$ が大き くなりストレッチャーストレインが発生するため変更するこ とができない，従って，N 量の低減を検討した.

図 9 に 含有量と絞り值の関係を示す. $\mathrm{N}$ 含有量を低減 させると断面減少率が増加し, 熱間延性は向上するため, 久 ラブ割れを回避することができると考えられる．以上より， 図10に示す開発 CAL 材の成分設計を行うことで連続鋳造条 件を変更することなくスラブ割れを回避することが可能とな った。

\section{5. ま ぬ め}

大型溶接缶の必要特性を満たし, 製造上の課題を解決した $\mathrm{CAL}$ 材の新 $\mathrm{Nb}-\mathrm{B}$ 複合添加極低炭素鋼板を開発した．これ にあたり，(1)溶接性向上，(2)再結晶温度上昇抑制，(3)熱間延 (a)

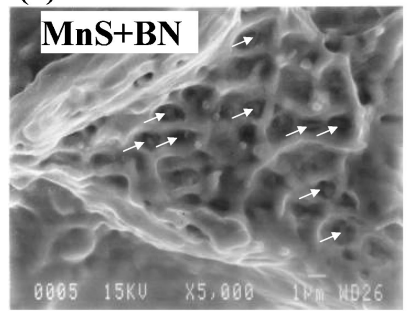

(b)

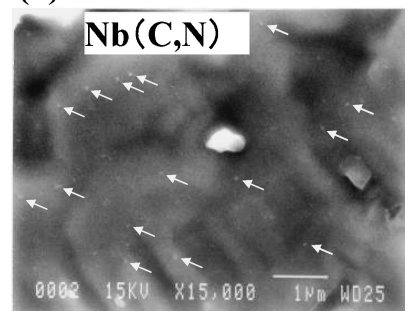

図 8 ラボ高温引張試験後の破断面の SEM 写真.

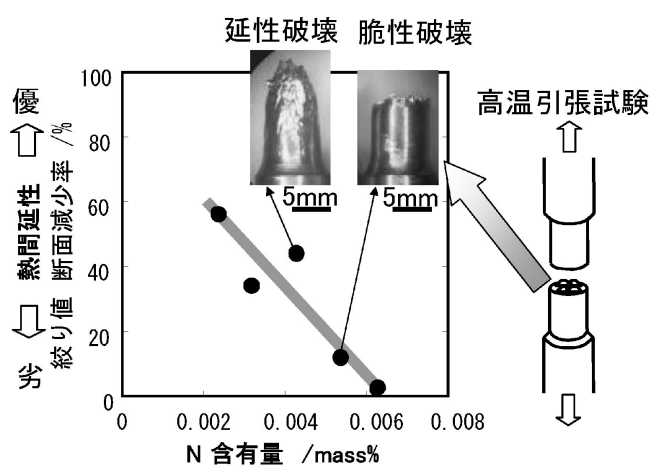

図 $9 \mathrm{~N}$ 含有量と絞り值の関係.

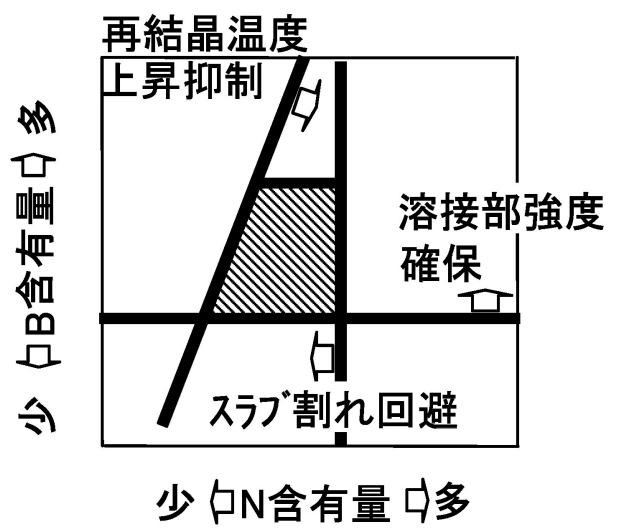

図10 開発 CAL 材の成分設計.

性低下抑制のため, $\mathrm{B}, \mathrm{N}$ 量の最適の成分設計を行った。溶 接性を要求される BAF 材が開発 CAL 材に順次切り替えら れ，錫鍍金工場の CAL 比率は $78 \%$ から $95 \%$ 飛躍的に向上 し，BAF 設備休止も実現可能であると考えられる．さらに 開発 CAL 材はアジアをはじめ海外へも供給されている.

\section{6. 特 許}

国内では特開2005-307350等が公開され，国外にも出願し ている.

\section{文献}

（1）堀田英輔, 保久光男, 川瀬幸夫：JFE 技報, 12 (2006), 34 .

（2）伊藤 庸, 中沢正敏, 中里嘉夫, 大橋延夫：川崎製鉄技報, 5 (1973), 224.

（3）苗村 博，野副 修，実川正治，下村隆良，小野 賢：鉄々 鋼, 67 (1981), S1178.

（4）細谷佳弘，橋本 哲，西本昭彦：極低炭素鋼板の金属学，日 本鉄鋼協会, (1993), pp. 179-190.

（5）安原英子, 坂田 敬, 古君 修：鉄と鋼, 85 (1999), 350. 